\title{
The Relationship of Parental Rearing Styles and Coping Styles of Middle School Students
}

\author{
Uma. $\mathbf{K}^{1}$, Manikandan. $\mathbf{K}^{2}$ \\ ${ }^{1}$ Senior Clinical Psychologist, Spandhana Centre, Calicut, India \\ ${ }^{2}$ Professor, Department of Psychology, University of Calicut, India
}

\begin{abstract}
In daily life, students are exposed to a wide range of potentially difficult academic situations, which could negatively affect their academic performance and health as well. To reduce this pressure related to academics, vital personality characteristics and parental support have an essential role. Among those factors, self-esteem and locus of control are the critical determinants for the coping aspects of the students. This will support student engagement, persistence, and academic success. Researches have given importance to the proactive approach, which emphasizes the prominence of coping strategies in preventing harmful consequences. In recent years, a growing emphasis has been given to the extent to which individuals can combine the different coping strategies and the adaptive consequences associated with them. However, studies related to person-centered approaches are still more minor in which a person's personality features and environment have a significant emphasis. In the current study, the researchers have put effort into understanding the influential role of self-esteem, locus of control, and perceived parenting styles on students' coping styles. The study tries to understand the level of involvement of the study variable in academic stress. For study 402, college students were randomly selected. A few scales like the perceived parenting style scale, brief self-esteem scale, locus of control scale, and brief cope scale were used to study the variables. To understand the influence of the variables, statistical analyses like 3 way ANOVA, t-test, and cell means were calculated to understand the interactions. The results show the interaction between parenting style, self-esteem, and locus of control. In turn, these have an impact on the coping patterns of the students.
\end{abstract}

Keywords: Academic achievement, Coping, College students, Locus of Control, Perceived Parenting Styles, Self-Esteem.

\section{Introduction}

The mental health of students has become a growing concern over the years. It is mainly dependent upon how they cope with situations during their educational period, as they are needed to face various academic demands. These could be academic and non-academic, affecting their psychological well-being. Academic related aspects include adaptation to a new context, overwork, insufficient time to do their academic tasks, preparation time for exams, and the pressure to perform (Vizoso \& Arias, 2016; Erschens, Werner, Keifenheim, Loda, Bugaj, Nikendei, Koppel, Zipfel, \& Junne, 2018). Along with that, non-academic aspects like new social relationships, conflicts with partners, family, and friends, and concerns about money and future work (Beiter, McCarthy, Rhoades, Linscomb, Clarahan, \& Sammut, 2015; Galatzer, Burton \& Bonanno, 2012; Howard, Schiraldi, Pineda, \& Campanella, 2006). In this context, how they cope-up-with and other psychological resources could act as a protective factor in dealing with such a situation.

Lazarus and Folkman (1984) explained stress as a process of interaction between the individual and environment. Its effect on the physical and psychological well-being of the individual is determined by coping. This is a widely known fact that coping is a cognitive and behavioural effort made in response to external or internal demands that individuals consider a threat to their wellbeing. It has been observed that most college students positively handle stress, but some of them may not know the appropriate ways of coping. Therefore, they end up with an unhealthy way of dealing with a situation. Thus, the perspective of coping should be explored as it involves different types of coping like emotional, cognitive, or social support seeking level. Kopp (1989) explained five types of coping behaviours: visual or physical avoidance, distraction, self-soothing, problemoriented, and care eliciting. An individual's coping style at one point in time may be unsuitable for another time. In such a situation, the flexibility and appropriateness of effective coping should be understood. This may be depended upon the cultural expectations, personality aspects, and family upbringing.

Among the different personalities and external environment, self-esteem and locus of control have an essential role in students coping with the situation. Moreover, self-esteem can help to understand the quality of life and other life circumstances of the students' college life. Self-esteem can be defined as a favourable or unfavourable attitude towards self (Rosenberg, 1965). Self-esteem is a significant factor in the academic life of a student as it is associated with good academic results and intrinsic motivation to learn (Navarro, Thomas, \& Oliver 2006). Similarly, low self-esteem is associated with peer rejection (Murray, Griffin, Rose \& Bellavia, 2003). It can also cause for internalised psychopathology (Gonzalez-Fortaleza \& Ruiz, 1993), academic failure, and dropout (Navarro, Tomas, \& Oliver, 2006). Self-esteem has a vital role in the psychological wellbeing of college students (Diener \& Diener, 1995; Paradise \& Kernis, 2002; Kang, Shaver, Sue, Min, \& Jing, 2003; Reid, 2004, Barra, 2012). Studies suggested that self-esteem was associated with more significant stress-related growth, which was helpful for a positive change that can emerge from a stressful situation (Dolbier, Jaggars, \& Steinhardt, 2009). In a study, Andreassen, Pallasen, and Griffith (2017) found that self-esteem is connected with stress in predicting depressive symptoms. Participants with higher self-esteem reported a lower level of depression than the participants who had lower self-esteem. Likewise, low self-esteem is associated with addictive behaviors. This is supported by a 
study that individuals' self-esteem is negatively related to compulsive social media applications.

Locus of control is another characteristic that can influence how you perceive the outcomes and how you deal with these outcomes effectively. Individuals who consider themselves able to control their outcomes are considered internal or possess an internal locus of control. On the other hand, individuals with an external locus of control often consider the outcome of any event beyond their control. These individuals will have high motivation to achieve their goals and low directedness (Zaidi \& Mohsin, 2013). Some studies have shown that individuals with an internal locus of control can be psychologically unhealthy and unstable if they decline competence, efficacy, and opportunity. It has been stated that they need suitable surroundings which inspire them to experience success. At the same time, externals may be easy-going, relaxed, and lead a pleasant life (Hans, 2000: Hattie, Marsh, Neil, \& Richards, 1997). An internal locus of control of an individual depends on one's permanent characteristics. Studies revealed that internal locus of control, self-esteem, and extraversions are associated with the hopelessness of the students, which will help them to cope with the situation (Balbag, Cemrek, \& Mutlu, 2010).

Students' perceptions of situations and responses influence the kind of parenting style they receive (Berger, 2011). Parents have a significant effect on students' lives, particularly in developing social and emotional aspects. They are the important people in a student's life and maybe one of the prime people a student looks to when making difficult decisions. Parents are often regarded as the chief socialization element for their children (Padilla-Walker, 2008). Through socialization, parents act as the emotional regulators for their children until they can regulate their own emotions and behaviours appropriately. The parenting styles impact adolescents' self-concept, locus of control, and academic achievement (Lee, Daniels, \& Kissinger, 2006).

In the present study, the researchers have made an effort to understand the influence of locus of control, self-esteem, and parenting styles on the coping style of students. Studies have shown the consequences of these variables independently. In this study, an effort has been placed to understand the interaction between these variables on the coping pattern of students. This will help to develop an approach where the students can be benefitted.

\section{Objective}

To find out the influence of locus of control, self-esteem, and parenting styles on students' coping styles.

\section{Hypotheses}

1) There will be significant main and interaction effects of locus of control, self-esteem, and perceived parenting style on students' coping styles.

2) There exist significant sex differences in coping styles among students.

\section{Method}

\section{Participants}

The participants of the study consisted of college students from different colleges situated in Bangalore, Karnataka. The participants belonged to different departments of the colleges. To select the participants, a random sampling method was used, consisting of 402 college students. Among the participants, 77 (19.2\%) were boys, and 325 (80.8\%) were girls. The students were from different streams like arts, commerce engineering, and polytechnic.

\section{Instruments}

1) Perceived Parenting Style Scale: The perceived Parenting Style Scale developed by Divya and Manikandan (2013) was used to measure the students' perception of their parent's behaviour. It measures the perceived parenting style of the participants with regard to three dimensions: authoritarian, authoritative, and permissive. It consists of 30 items in which responses were elicited in a five-point Likert scale (Strongly Agree to Strongly Disagree. Authors of the scale reported reliability for each dimension. The reliability coefficient of 0.79 for authoritative, 0.81 for authoritarian, and for permissive is 0.86 . The authors claim that the scale has face validity.

2) Brief Self-Esteem Inventory: This inventory was developed by Williams (2002) to measure people's selfesteem and consists of 20 items. The responses of the inventory were obtained on a 4 point Likert scale. Sample statements of the inventory are "I consider my ability to think and reason adequate," "I am satisfied with the degree of success I am experiencing so far in my life, " showing the participants' self-esteem aspect. The higher the score, the higher will be the self-esteem. The author reported a reliability coefficient Alpha as 0.68 and test re-test reliability 0.70 . The inventory has construct validity.

3) Locus of Control Scale: The locus of control of the respondents was measured using the Locus of Control Scale developed by Nowicki and Duke (1974). The items in the scales were towards external locus of control orientation (E.g. Are you blamed for things that just aren't your fault? Do you feel that the best way to handle most problems is not to think about them?). The high score indicates an external locus of control, and the lower score shows the internal locus of control. The scale has a test re-test reliability of 0.83 , and the validity of the scale is correlating well with the original Rotter scale (e. g., Correlation with Marlowe-Crowne Social Desirability Scale ranged between-0.41 and-0.12: Rotter, 1966), and it is related to other variables in the same way that the original scale.

4) Brief COPE Scale: The Brief COPE Scale, a 12 item scale developed by Uma and Manikandan (2013), was used to measure students' coping styles. Responses were elicited in terms of a four-point Likert scale. The scores for the responses are 1, 2, 3, and 4. On the scale, the score indicates a higher coping skill, and the lower the score, the poorer will be coping skills. The maximum score is 56 , and the minimum score is 14 . The scale's reliability was established by calculating Cronbach 
Alpha, and it was found to be 0.67 , and the test-retest reliability was found to be 0.72 . The authors claim that the instrument has adequate face validity.

5) Personal Data Sheet: To collect information such as sex, age, subject of study, year of study of the participants, ' Personal data sheet was used.

\section{Procedure}

The researchers contacted the head of the institutions and discussed the objective, purpose, and significance of the study and requested sincere support. Then they were introduced to the class teacher/mentor of the concerned classes. The purpose and nature of the study were also explained to the teacher. Then gave a brief introduction about the research and purpose to the students. The researcher established rapport with the students and requested their consent for participation in the study. After obtaining their written consent, the research instruments were administered. Researchers gave a detailed description of marking the responses and clarified their doubts. The participants were assured that their responses would be kept confidential and used only for research purposes. After completion, the instruments were collected and checked for the omission, and those found incomplete were omitted. The scoring of these instruments was done according to the scoring manual, and then the data was fed into a spreadsheet for further statistical analysis.

\section{Results and Discussion}

Learners as individuals generally have stress, and much of this will be connected to academic activity. Today's learners experience unexpected demands from universities or potential employers. Students have to balance the pressure exerted by the syllabus or teachers and irrational expectations of job providers. But the experience gained through the student's life span, the majority of them might have developed a skill to adjust or cope with the stress. While adapting the strategy to cope with the situation or problem, psychological variables like self-esteem, locus control, and parenting styles may have a significant role. It is essential to understand the role of the variables. In turn, it will help to provide interventions to students who undergo stress. Here the investigators tried to understand the influence of self-esteem, locus of control, and perceived parenting style on coping style; for this, three-way ANOVA was computed, and the results are presented in Table 1.

Table 1: Summary of ANOVA of Coping styles by Self-esteem, Locus of control and Authoritative parenting style $(2 \times 2 \times 2)$

\begin{tabular}{|c|c|c|c|c|}
\hline Source of variance & Sum of Squares & df & Mean Square & F \\
\hline Self-Esteem & 647.211 & 1 & 647.211 & $23.95^{* *}$ \\
\hline Locus of Control & 24.153 & 1 & 24.153 & 0.894 \\
\hline Authoritative Parenting Style & 142.182 & 1 & 142.182 & $5.26^{*}$ \\
\hline Self Esteem * Locus of Control & 0.694 & 1 & 0.694 & 0.03 \\
\hline Self Esteem * Authoritative Parenting Style & 35.559 & 1 & 35.559 & 1.32 \\
\hline Locus of Control * Authoritative Parenting Style & 5.329 & 1 & 5.329 & 0.19 \\
\hline $\begin{array}{c}\text { Self Esteem * Locus of Control * Authoritative Parenting } \\
\text { Style }\end{array}$ & 98.174 & 1 & 92.174 & \multirow{2}{*}{3.63} \\
\hline Error & 10649.028 & 394 & 27.028 & \\
\hline
\end{tabular}

$* \mathrm{p}<.05 . * * \mathrm{p}<.01$

From table 1, it can be seen that no three-way and two-way interaction exist among self-esteem, locus of control, and perceived authoritative parenting style on coping styles of the participants. But there was a significant independent main effect of self-esteem $(\mathrm{F}=23.95, \mathrm{p}<.01)$ and authoritative parenting $(\mathrm{F}=5.26, \mathrm{p}<.05)$ on coping styles of the participants. This indicates that the self-esteem of the individual influences their coping styles. Kerney (1999) reported that adolescents with high self-esteem would cope well in life situations. The results also revealed that perceived authoritative parenting style has an independent effect on the coping style of the participants. According to Finkenauer, Engels, and Baumeister (2005), parents who are strict but supportive and show acceptance have better-coping styles in adolescents. To verify the group difference, the mean scores of low and high self-esteem groups and high and low authoritarian groups were compared using a t-test, and the results are presented in Table 2.

Table 2: Mean, $\mathrm{Sd}$, and ' $\mathrm{t}$ ' value of Coping style by Self-esteem and Authoritative Parenting Style

\begin{tabular}{|c|c|c|c|c|c|}
\hline Variables & Group & N & Mean & S D & 't' Value \\
\hline \multirow{2}{*}{ Self Esteem } & High & 213 & 101.09 & 8.833 & \multirow{2}{*}{$18.52 * *$} \\
\cline { 2 - 5 } & Low & 189 & 116.71 & 7.978 & 10.978 \\
\multirow{2}{*}{$\begin{array}{c}\text { Authoritative } \\
\text { Parenting Style }\end{array}$} & High & 205 & 109.85 & $1.54 *$ \\
\cline { 2 - 5 } & Low & 197 & 106.96 & 1.848 & \\
\hline
\end{tabular}

$* \mathrm{p}<.05 . * * \mathrm{p}<.01$

From table 2, it can be seen that self-esteem $(\mathrm{t}=18.52, \mathrm{p}<.01)$ and perceived authoritative parenting $(\mathrm{t}=2.54, \mathrm{p}<.05)$ have significant influence on adolescents coping style. The mean score on self-esteem was high in the low self-esteem group (Mean=116.71), and the mean score on perceived authoritative parenting showed a higher score on high authoritative parenting (Mean=109.85). The study showed that adolescents with low self-esteem and high perceived authoritative parenting style would have a better coping style.

To know the extent of coping by self-esteem, locus of control, and authoritative parenting style, the investigator 
has calculated the cell means, and the details are given in table 3.

Table 3: Cell means of Coping Style by Self-esteem, Locus of control and Authoritative parenting style

\begin{tabular}{|c|c|c|c|c|c|}
\hline \multicolumn{2}{|c|}{ Grouping Variable } & \multicolumn{2}{|c|}{ Low Authoritative parenting style } & \multicolumn{2}{|c|}{ High Authoritative parenting style } \\
\hline \multirow{6}{*}{ Low Self Esteem } & \multirow{3}{*}{ Internal Locus of control } & Mean & 35.41 & Mean & 34.32 \\
\hline & & $\mathrm{SD}$ & 5.01 & $\mathrm{SD}$ & 5.08 \\
\hline & & $\mathrm{N}$ & 80 & $\mathrm{~N}$ & 53 \\
\hline & \multirow{3}{*}{ External Locus of control } & Mean & 36.65 & Mean & 33.95 \\
\hline & & SD & 5.43 & SD & 4.62 \\
\hline & & $\mathrm{N}$ & 23 & $\mathrm{~N}$ & 57 \\
\hline \multirow{6}{*}{ High Self Esteem } & \multirow{3}{*}{ Internal Locus of control } & Mean & 38.44 & Mean & 36.51 \\
\hline & & $\mathrm{SD}$ & 5.84 & $\mathrm{SD}$ & 5.62 \\
\hline & & $\mathrm{N}$ & 61 & $\mathrm{~N}$ & 37 \\
\hline & \multirow{3}{*}{ External Locus of control } & Mean & 38.17 & Mean & 37.61 \\
\hline & & SD & 5.52 & SD & 5.37 \\
\hline & & $\mathrm{N}$ & 102 & $\mathrm{~N}$ & 87 \\
\hline
\end{tabular}

Table 3 shows the cell means of coping style by self-esteem, locus of control, and perceived authoritative parenting style of the participants. From the table, it can be seen that participants with high self-esteem, internal locus of control, and low perceived authoritative parenting have the highest mean score in coping styles (Mean $=38.44)$. At the same time, participants with low self-esteem, external locus of control, and high perceived authoritative parenting style show the lowest amount of coping styles (Mean $=33.95)$.

Table 4: Summary of ANOVA of Coping styles by Self esteem, Locus of control and Authoritarian parenting style $(2 \times 2 \times 2)$

\begin{tabular}{|c|c|c|c|c|}
\hline Source of variance & $\begin{array}{c}\text { Sum of } \\
\text { Squares }\end{array}$ & df & $\begin{array}{c}\text { Mean } \\
\text { Square }\end{array}$ & F \\
\hline Self Esteem & 848.319 & 1 & 848.319 & $30.764 * *$ \\
\hline Locus of Control & 0.117 & 1 & 0.117 & 0.004 \\
\hline Authoritarian Parenting Style & 1.21 & 1 & 1.21 & 0.044 \\
\hline Self Esteem * Locus of Control & 10.451 & 1 & 10.451 & 0.379 \\
\hline Self Esteem * Authoritarian Parenting Style & 5.303 & 1 & 5.303 & 0.192 \\
\hline Locus of Control * Authoritarian Parenting Style & 19.435 & 1 & 19.435 & 0.705 \\
\hline $\begin{array}{c}\text { Self Esteem * Locus of Control * Authoritarian } \\
\text { Parenting Style }\end{array}$ & 7.565 & 1 & 7.565 & 0.274 \\
\hline Error & 10864.582 & 394 & 27.575 & \\
\hline Total & 541717 & 402 & & \\
\hline
\end{tabular}

$* * \mathrm{p}<.01$

Table 4 gives the results of three-way ANOVA. From the table, it can be seen that no three-way or two-way interaction exists among self-esteem, locus of control, and authoritarian parenting on coping styles. But self-esteem has a significant main effect on coping styles $(F=30.764$, $\mathrm{p}<.01)$. This explains that there is a significant influence of self-esteem on the coping styles of adolescents.

The cell means were calculated to understand the extent of self-esteem, locus of control, and authoritarian parenting on coping styles. The details of the results are presented in Table 5

Table 5: Cell means of Coping Style by Self-esteem, Locus of control and Authoritarian parenting style

\begin{tabular}{|c|c|c|c|c|c|}
\hline \multicolumn{2}{|c|}{ Grouping variable } & \multicolumn{2}{|c|}{ Low Authoritarian parenting style } & \multicolumn{2}{|c|}{ High Authoritarian parenting style } \\
\hline \multirow{6}{*}{ Low Self Esteem } & \multirow{3}{*}{ Internal Locus of control } & Mean & 35.27 & Mean & 34.71 \\
\hline & & SD & 4.68 & SD & 5.38 \\
\hline & & $\mathrm{N}$ & 63 & $\mathrm{~N}$ & 70 \\
\hline & \multirow{3}{*}{ External Locus of control } & Mean & 34.77 & Mean & 34.58 \\
\hline & & SD & 4.68 & $\mathrm{SD}$ & 6.03 \\
\hline & & $\mathrm{N}$ & 61 & $\mathrm{~N}$ & 19 \\
\hline \multirow{6}{*}{ High Self Esteem } & \multirow{3}{*}{ Internal Locus of control } & Mean & 38.16 & Mean & 37.51 \\
\hline & & SD & 5.41 & SD & 6.01 \\
\hline & & $\mathrm{N}$ & 31 & $\mathrm{~N}$ & 31 \\
\hline & \multirow{3}{*}{ External Locus of control } & Mean & 37.77 & Mean & 38.69 \\
\hline & & SD & 5.36 & SD & 4.54 \\
\hline & & $\mathrm{N}$ & 56 & $\mathrm{~N}$ & 35 \\
\hline
\end{tabular}

Table 5 shows the cell means of coping style by self-esteem, locus of control, and perceived authoritarian parenting style.
Even though there was no significant interaction, the cell mean gives a picture of the group's coping style. The table 
shows that participants with high self-esteem, external locus of control, and low perceived authoritarian parenting have the highest coping skills $($ Mean $=38.69)$. The participants with low self-esteem, external locus of control, and high perceived authoritarian parenting style have the lowest coping styles $($ Mean $=34.58)$.

Table 6: Summary of ANOVA of Coping styles by Self-esteem, Locus of control and Perceived Permissive parenting style $(2 \times 2 \times 2)$

\begin{tabular}{|c|c|c|c|c|}
\hline Source of variance & Sum of Squares & df & Mean Square & F \\
\hline Self Esteem & 895.901 & 1 & 895.901 & $32.49^{* *}$ \\
\hline Locus of Control & 0.408 & 1 & 0.408 & 0.02 \\
\hline Permissive Parenting Style & 0.631 & 1 & 0.631 & 0.02 \\
\hline Self Esteem * Locus of Control & 10.41 & 1 & 10.41 & 0.38 \\
\hline Self Esteem * Permissive Parenting Style & 1.089 & 1 & 1.089 & 0.04 \\
\hline Locus of Control * Permissive Parenting Style & 5.788 & 1 & 5.788 & 0.21 \\
\hline Self Esteem * Locus of Control * Permissive Parenting Style & 28.128 & 1 & 28.128 & 1.02 \\
\hline Total & 10864.831 & 394 & 27.576 & \\
\end{tabular}

$* * \mathrm{p}<.01$

Table 6 gives the results of three-way ANOVA on coping styles by Self-esteem, Locus of control, and perceived permissive parenting style. Results revealed no three-way or two-way interaction among the variables on coping styles. There was an independent effect of self-esteem on coping styles $(\mathrm{F}=32.49, \mathrm{p}<.01)$. This explains self-esteem of the participants played a crucial role in the coping styles of adolescents. To know more about the mean scores of these variables on coping styles, the cell means were calculated. The details of the results are presented in Table 7 .

Table 7: Cell means of Coping Style by Self-esteem, Locus of control and Permissive parenting style

\begin{tabular}{|c|c|c|c|c|c|}
\hline \multicolumn{2}{|c|}{ Grouping variable } & \multicolumn{2}{|c|}{ Low Permissive parenting style } & \multicolumn{2}{|c|}{ High Permissive parenting style } \\
\hline \multirow{6}{*}{ Low Self-Esteem } & \multirow{3}{*}{ Internal Locus of control } & Mean & 34.77 & Mean & 35.11 \\
\hline & & SD & 5.42 & SD & 4.82 \\
\hline & & $\mathrm{N}$ & 53 & $\mathrm{~N}$ & 80 \\
\hline & \multirow{3}{*}{ External Locus of control } & Mean & 34.81 & Mean & 34.52 \\
\hline & & SD & 4.91 & SD & 5.29 \\
\hline & & $\mathrm{N}$ & 57 & $\mathrm{~N}$ & 23 \\
\hline \multirow{6}{*}{ High Self-Esteem } & \multirow{3}{*}{ Internal Locus of control } & Mean & 38.33 & Mean & 37.31 \\
\hline & & SD & 5.55 & SD & 5.98 \\
\hline & & $\mathrm{N}$ & 39 & $\mathrm{~N}$ & 59 \\
\hline & \multirow{3}{*}{ External Locus of control } & Mean & 37.92 & Mean & 38.55 \\
\hline & & SD & 5.35 & SD & 4.41 \\
\hline & & $\mathrm{N}$ & 62 & $\mathrm{~N}$ & 29 \\
\hline
\end{tabular}

Table 7 shows the cell means of coping style by self-esteem, locus of control, and authoritarian parenting style. Even though there was no significant interaction, the cell mean score explains the group in which the coping style is more. From table 7, it can be seen that participants with high selfesteem, external locus of control, and low perceived permissive parenting have the highest coping skills (Mean $=$ 38.55). The participants with low self-esteem, external locus of control, and high perceived permissive parenting style have the lowest coping styles (Mean $=34.52$ ).

\section{Conclusion}

The variables self-esteem, locus of control, and perceived parenting style influence coping styles. Results showed no significant interaction between self-esteem and locus of control of adolescents but they independent effects on coping styles. It has been depicted that these variables have an important role in developing coping strategies. This understanding will help provide ample support to students in dealing with difficult situations in college. Providing the importance of parenting will help to parent's perspective, which will impact changes in the behavioral pattern of students. This will help the students to learn the path of education, which the conceptual model of higher education explains. In this, the students learn functional, professional, and social responsive knowledge. This will help the students understand a concept from a societal perspective and become more socially responsible.

\section{References}

[1] Andreassen, C. S., Pallesen, S., \& Griffiths, M, D. (2017). The relationship between addictive use of social media, narscissm and self-esteem: Findings from a large national survey, Addictive Behaviour, 64, 287-293 doi: 10.1016/j. addbeh.2016.03.006.

[2] Balbag, Z., Cemrek, F., \& Mutlu, T. (2010). The role of selfesteem, locus of control and big five personality traits in predicting hopelessness. Procedia Social and Behavioral Sciences, 9, 1788-1792.

[3] Barra, E. (2012). Influencia de la autoestima y del apoyo social percibidosobre el bienestarpsicológico de estudiantesuniversitarioschilenos [Influence of SelfEsteem and Perceived Social Support on the Psychological Well Being of Chilean University Students]. Diversitas: PerspectivasenPsicología [edición online], 8 (1), 29-38. 
[4] Beiter, R., Nash, R., McCrady, M., Rhoades, D., Linscomb, M., Clarahan, M., et al. (2015). The prevalence and correlates of depression, anxiety, and stress in a sample of college students. Journal of Affective Disorder.173, 90-96. doi: 10.1016/j. jad.2014.10.054

[5] Berger, S. K. (2011). The Developing Person through the Life Span.8th ed. Worth Publishers, 273-278.

[6] Diener, E., \& Diener, M. (1995). Cross-cultural Correlates of Life Satisfaction and Self-esteem. Journal of Personality and Social Psychology, 68 (4), 653-663.

[7] Divya, T. V., \& Manikandan, K. (2012). Perceived parenting style inventory. Department of Psychology, Calicut: University of Calicut.

[8] Dolbier, C. L., Jaggars, S. S., \& Steinhardt, M. A. (2009). Stress-related growth: Pre-intervention correlates and change following a resilience intervention. Stress and Health, 26, 135-147. doi: http: //dx. doi. org. ezproxy. fhsu. edu: 2048/10.1002/smi.1275

[9] Erschens, R., Herrmann-Werner, A., Keifenheim, K. E., Loda, T., Bugaj, T. J., Nikendei, C., et al. (2018). Differential determination of perceived stress in medical students and high-school graduates due to private and training-related stressors. PLoS One 13: e0191831. doi: 10.1371/journal. pone.0191831

[10] Finkenauer, C., Engels, R. C. M. E., \& Baumeister, R. F. (2005). Parenting behaviour and adolescent behavioural and emotional problems: The role of self-control. International Journal of Behavioral Development, 29, 5869.

[11] Galatzer-Levy, I. R., Burton, C. L., \& Bonanno, G. A. (2012). Coping flexibility, potentially traumatic life events, and resilience: a prospective study of college student adjustment. Journal of Social and Clinical Psychology 31, 542-567. doi: 10.1521/jscp.2012.31.6.542

[12] González-Fortaleza, \& Ruiz, E. (1993). Autoestima y sintomatologíadepresivaenadolescentesmexicanos: un estudiocorrelacionalporgénero [Self-Esteem and Depressive Symptoms in Mexican Adolescents: A Gender-Based Correlational Research]. RevistaABPAPAL, 15 (2), 59-64.

[13] Hans, T. (2000). A meta-analysis of the effects of adventure programming on locus of control. Journal of Contemporary Psychotherapy, 30 (1), 33-60.

[14] Hattie, J. A., Marsh, H. W., Neill, J. T., \& Richards, G. E. (1997). Adventure Education and Outward Bound: Out of class experiences that have a lasting effect. Review of Educational Research, 67, 43-87.

[15] Howard, D. E., Schiraldi, G., Pineda, A., \& Campanella, R. (2006). Stress and mental health among college students: overview and promising prevention interventions, In M. V. Landow (Ed) Stress and Mental Health of College Students, New York, NY: Nova Science Publishers.

[16] Kang, S., Shaver, P., Sue, S., Min, K., \& Jing, H. (2003). Culture-specific Patterns in the Prediction of Life Satisfaction: Roles of Emotion, Relationship Quality, and Self-esteem. Personality and Social Psychology Bulletin, 29, 1596-1608. DOI: 10.1177/0146167203255986.

[17] Kearney, C, A. (1999). Gender Differences and selfesteem, Journal of Gender specific Medicine, 2 (3), 4652.

[18] Kopp, C. B. (1989). Regulation of distress and negative emotions: A developmental view. Developmental Psychology, $25 \quad$ (3), 343-354. https: //doi. org/10.1037/0012-1649.25.3.343
[19] Lazarus, R. S., \& Folkman, S. (1984). Stress, Appraisal, and Coping. New York, NY: Springer.

[20] Lee, S. M., Daniels, M. H., \& Kissinger, D. B. (2006). Parental influences on adolescent adjustment: Parenting styles versus parenting practices. The Family Journal, 14 (3), 253-259 DOI: 10.1177/1066480706287654

[21] Murray, S. L., Griffin, D. W., Rose, P., \& Bellavia, G. M. (2003). Calibrating the Sociometer: The Relational Contingencies of Self-esteem. Journal of Personality and Social Psychology, 85, 63-84. DOI: 10.1037/00223514.85.1.63

[22] Musitu, G., \& Cava, M. J. (2003). El rol del apoyo social en el ajuste de losadolescentes [The Role of Social Support in Adjustment in Adolescents] IntervenciónPsicosocial, 12 (2), 179-192.

[23] Navarro, E., Tomás, J. M., \& Oliver, A. (2006). Factorespersonales, familiares y académicosenniños y adolescentes con bajaautoestima [Personal, Family and Academic Factors in Children and Adolescents with Low Self-Esteem]. Boletín de Psicología, 88, 7-25.

[24] Nowicki, S., \& Duke, M. P. (1974). Locus of control scale. Journal of Personality Assessment, 38, 136-137

[25] Padilla-Walker, L. M. (2008). Domain-appropriateness of maternal discipline as a predictor of adolescents' positive and negative outcomes. Journal of Family Psychology, 22 (3), 456-464. https: //doi. org/10.1037/08933200.22.3.456

[26] Paradise, A., \& Kernis, M. (2002). Self-esteem and Psychological Well Being: Implications of Fragile Selfesteem. Journal of Social and Clinical Psychology, 21 (4), 345-361. DOI: 10.1521/jscp.21.4.345.22598.

[27] Reid, A. (2004). Gender and Sources of Subjective Well Being. Sex Roles, 51 (11/12), 617-629. DOI: 10.1007/s11199-004-0714-1.

[28] Rosenberg, M. (1965). Society and the adolescent selfimage. Princeton, NJ: Princeton University Press.

[29] Uma, K., \& Manikandan, K. (2013b). Brief COPE scale. Department of Psychology, Kerala: University of Calicut.

[30] Vizoso, C. M., \& Arias, O. (2016) Estresoresacadémicospercibidosporestudiantesuniversitari os y surelación con el burnout y el rendimientoacadémicos [Academic stressors perceived by university students and their relationship with academic burnout, efficacy and performance]. Anu. Psicol.46, 9097. doi: 10.1016/j. anpsic.2016.07.006

[31] Williams, K. (2000). Brief self-esteem Inventory, International training partners, Inc.

[32] Zaidi, I. H., \& Mohsin, M. N. (2013). Locus of Control in Graduation Students. International Journal of Psychological research, 15-20. 